\title{
DEBAT IN DE TWEEDE KAMER DER STATEN-GENERAAL OVER ONZE CONSULS.
}

In de Tweede Karner der Staten-Generaal heeft op 4 December de heer Hintzen in krasse bewoordingen zijn twijfel uitgesproken aan het nut voor onzen handel van onze Consulaten in den vreemrle.

Waar dit geschiedde door een serieus en bekwaam man, vroeger lid van een der geachtste handelsfirma's te Rotterdam, en door die stad afgevaardigd naar de Tweede Kamer, dáár heeft dit meer dan gewone beteekenis. Toch vrees $\mathrm{ik}$, dat die geachte afgevaardigde zich te veel heeft laten influenceeren door zijn sceptische eenigzins bittere, manjer van beschouwing over handelszaken. Al dadelijk is het opvallend, dat die meening afwijkt van de opvatting, die bestaat bv. in Engeland, Duitschland en Oostenrijk. In die landen is men steeds bezig het Consulaatwezen uit te breiden door het aanstellen van gesalarieerde Consuls. Met groote waardeering wordt dáár in de bladen, die aan den handel gewijd zijn, over de werkzaamheden der Consuls gesproken. In de Engelsche Economist bv. komen herhaaldelijk berichten voor, die de Engelsche Consuls geven over de oorzaken van mindere of meerdere toename van den handel van Engeland of van andere Staten op die verschillende plaatsen in het buitenland; en gedurig wijst dat blad op de behartingswaardige wenken, door de Consuls gegeven. Ik behoef er bv. maar op te wijzen, hoe de Engelsche Consuls herhaaldelijk releveeren, dat de toeneming van het Duitsche Handelsverkeer o. a. te wijten is hieraan, dat de Duitschers goedkooper artikelen ECON. 1891. 
leveren dan de Engelschen, en dat zij het land laten rondreizen door agenten, die de taal van het land kennen, hetgeen de Engelschen te weinig doen. Dit een en ander wordt dan met speciaal genoemde fabrikaten aangetoond.

Voor het ontwikkelen van het handelsverkeer zullen onze Consulaten binnen Europa niet veel nut doen, omdat die plaatsen allen in korten tijd te bereiken zijn. Hierover is men het overal eens. Toch zijn die Consulaten in een ander opzicht nuttig. Vooreerst omdat zij van advies kunnen dienen Hollanders, die op die plaatsen komen om zaken te doen; maar ook omdat zij in hun jaarverslag een beeld kunnen geven van den toestand van handel en scheepvaart van hunne plaats, en van hetgeen door de overheid daarvoor gedaan wordt. Dat kan een Hollander beter doen, omdat hij, wetende hoe de zaken hier te lande zijn, beter kan opmerken wat voor ons van belang is. Zoo kan het uitnemend verslag van den Consul-Generaal te Hamburg, den Heer von Schmidt Pauli (waarschijnlijk opgesteld door den Vice-Consul, den Heer Bosschart) als model dienen van hetgeen een Consulaat binnen Europa kan doen. Buiten Europa kan de Consul veel nut doen tot voorlichting van orzen handel of van ons fabriekswezen

De Heer Hintzen zeide: "Maar te meenen, dat aan oonze handelaars de weg gewezen kan worden door "Regeeringsambtenaren, en dat het verkeer zich daarnaar )zal richten, is een dwaling. Hunne inlichtingen zullen monze natie nooit tot een groote handelsnatie maken » (dit beweert ook niemand, en is ook wel wat veel gevergd van onze Consuls) " wen zal niet gunstig terug wer»ken op de energie van onze kooplieden. Fabriekanten wen importeurs, die wachten op de berichten van )Consuls, op hunne verzamelingen van stalen en monwsters, om daarop hunne zaken te baseeren zullen het mniet ver brengen; ik zou in hunne ondernemingen »niet gaarne een aandeel nemen.) Neen, daarin zal 
geen verstandig man aandeel nemen, maar zóó handelt nok geen verstandig koopman. Door de berichten van den Consul worden de kooplieden of fabriekanten op iets attent gemaakt; zij vragen dan aan den Consul het adres van een vertrouwd handelaar op de plaats, en openen met deze een relatie door nadere inlichtingen of staten te vragen. Zóó zouden onze Consuls kunnen getuigen, dat gedurig gedaan wordt; in sommige consulaire verslagen wordt uitdrukkelijk gemeld, dat dit gebeurt. 1) Maar ook het omgekeerde ziet men in die verslagen, dat de Consul waarschuwt tegen schoonklinkende aanbiedingen, of schoonschijnende voorstellingen van gewetenlooze handelaren op liun plaats.

"Dat er iets anders noodig is om handelsbetrekkingen (te vestigen dan de werkzaamheid van een Consul) zooals de heer Hintze zeiden, dit spreekt wel van zelf; maar het aan de Consuls te Calcutta en te Melbourne kwalijk te nemen, dat zij wijzen op verschillende Hollandsche artikelen, die ind i rect reeds daar heen gezonden worden, of die daarheen : gezonden zouden kunnen worden, en die voor een Hollandsch handelshuis een voldoende aliment zouden geven, dat verwijt gaat toch wel wat ver.

Tegen het minachtend neerzien, dat de heer $\mathrm{H}$. doet op de Vereeniging het Buitenland béhoef ik die instelling net verdedigen. Wat de Secretaris dier Vereeniging, de heer G. M. Boissevain te Amsterdam, voor die zaak in 't belang van onzen handel en van onze nijverheid doet, is boven mijn lof verheven. De heer H. zegt: «On«getwijfeld getroost die Vereeniging zich de opoffering «van veel geld en tijd, om jeugdige Nederlanders in den

1) Een analoog vourbeeld heb ik in mijne omgeving gezien. Een Amerikarsohe Congul, en Consul missus, geen handelar, in een Fingeische bezibting, bad de beleefdheid zijn geirukt consulair. rapport te zender sau een handelanr allier, hem er op attent makende dat hij een artikel, waarin hij haudel dreef, van dáár kon betrekken. En daaruit is oen zeer belangrijke en zeer winstgevende, directe handel ontstaan voor dien bandelaar, alhier. 
(vreemde op handelskantoren te plaatsen. Ts het waar(schijnlijk, dat die bemoeiingen zullen ten gevolge hebben, «dat daardoor internationale betrekkingen ontstaan? De (toekomst zal hierop het antwoord geven.» Zeker, men kan dit niet vooruit zeggen. Maar het is toch niet geheel zonder grond, dat die Vereeniging de zaak begonnen is. Zij had het voorbeeld, hoe in Oostenrijk en in Belgie diergelijke pogingen uitstekende resultaten gehad hadden. Zij had ook het voorbeeld van fabrikanten alhier, die jongelui bij zich hadden opgekweekt, welke later naar overzeesche, vreemde landen gingen als bedienden op kantoren aldaar, en die de Hollandsche fabrikanten hebben geïntroduceerd. Dat ligt toch ook in den aard der zaak. Dit is de manier, waarop de Duitschers zoo énorm zijn vooruitgegaan in het vestigen van hun buitenlandsche clientèle voor hun fabrikaten. En wanneer nu die Vereeniging jongelui uitzendt op aanraden en onder medewerking van Hollandsche Consuls, die hun ook tijdens hun verblijf met raad en daad bijstaan, dan doen die consuls en dan doet die Vereeniging een nuttig werk voor ons land.

Uit den aard der zaak zal onze Consul buitenlands, als hij bv. een Duitscher is, niet met zóóveel ijver werken voor het vermeerderen van on ze handelsbetrekkingen met dat land, als een Hollander dit doet. Daarom juist dringen de Kamers van Koophandel er steeds op aan, en wordt ook aan ons Ministerie van Buitenlandsche Zaken getracht, zooveel mogelijk Hollanders tot Consuls te benoemen. En dat in grootere plaatsen Consules missi gewenscht zijn, vindt hierin zijn oorzaak, dat een handelaar-Consul uit den aard der zaak liever geen nieuwe handelsbuizen als concurrenten ziet komen in zijne stad; en omdat handelaars en fabriekanten hier te lande met meer vertrouwen informatien vragen door tusschenkomst van Consuls, die zelve geen handelaars zijn.

Dat de Kamers van Koophandel moeielijk ontkennend kunnen antwoorden, wanneer de Minister haar advies 
vraagt over de oprichting van bezoldigde consulaten (zoo als de heer Hintzen zegt), is onjuist. Maar wel waar is, dat die Kamers uit eigen beweging dikwijls bij den Minister hebben aangedrongen op het vestigen van bezoldigde consulaten; ook waar is het, dat de Kamers dikwijls hebben afgeraden Consuls te benoemen, op plaatsen waar de Minister voorstelde dit te doen.

De Minister van Tienhoven heeft met groot talent ook dit gedeelte van zijn begrooting verdedigd. Maar uit den aard der zaak kon hij over een onderdeel, als dit, niet zeer uitvoerig zijn. Ik meende daarom, dat het goed was, als uit den handel een stem opging tegen den m.i. onverdienden uitval van een landsvertegenwourdiger tegen de zoo nuttige instelling van onze Consulaten.

M. MeEs. 